[Regular Paper]

\title{
Novel Combination Process of Heavy Oil Cracking Using Disposable Additive Catalyst
}

\author{
${\text { Koichi } \mathrm{KATO}^{\dagger 1)^{*}} \text {, Katsuaki IsHIDA }}^{\dagger 2)}$, Yasushi IshIBASHI ${ }^{\dagger 3)}$, and Akira SAITO ${ }^{\dagger 3)}$ \\ †1) Nikko Consulting \& Engineering Co., Ltd., 4-1-40 Toranomon, Minato-ku, Tokyo 105-0001 \\ 12) Petroleum Refining Research \& Technology Center, Japan Energy Corp., 3-17-35 Niizo-minami, Toda, Saitama 335-0026 \\ †3) Mizushima Oil Refinery, Japan Energy Corp., 2-1 Ushiodori, Kurashiki, Okayama 712-8504
}

(Received November 25, 1997)

\begin{abstract}
A novel combination process, SUCCEED, for residual oil cracking was developed by bench scale testing, and it has been proven commercially feasible. SUCCEED is a combination of slurry phase hydrocracking and delayed coking. In the first section, which is the main feature of the process, a tubular reactor with a small amount of disposable additive catalyst is applied. For the vacuum residue feedstock, the first section gives moderate conversion around $65 \mathrm{wt} \%$ and the second gives conversion around $55 \mathrm{wt} \%$ for the unconverted feed in the first section, thus resulting in the total conversion of $85 \mathrm{wt} \%$.

The functions of the catalyst, hydrogenation ability and anti-coking effect on the reactor have been studied to determine the minimum requirement of catalyst consumption rates.

In this study, characteristics, capabilities and effect of the catalyst are discussed. And, in particular, features, performance and commercial feasibility of SUCCEED have been described.
\end{abstract}

\section{Introduction}

The conversion of the heaviest fraction of crude oil into more valuable and lighter products has been the primary goal of petroleum refining almost since its inception. Today, this goal is becoming even more important as both the demand for heavy fuel oil and the known reserves of the world's crude are continuing to decline. There are quite a few number of residue upgrading processes at various stages of commercial development. Among them, slurry phase hydrocracking using a disposable ultrafine powder catalyst seems to be one of the most attractive, future commercially feasible processes.

Japan Energy Corporation has developed a new process for residual oil cracking by bench testing. The new process, SUCCEED, is a combination of slurry phase hydrocracking and delayed coking. The first section is the main feature of SUCCEED in which the reaction is carried out in a tubular reactor with a small amount of disposable ultrafine powder catalyst that causes no problems on the reaction and the quality of the delayed coking feedstock. Using a vacuum residue feedstock, the first section gives conversion about $65 \mathrm{wt} \%$ and the second covers conversion around $55 \mathrm{wt} \%$ for the unconverted feed in the first section, thus resulting in the total conversion of $85 \mathrm{wt} \%$. A flow diagram of the combination process, SUCCEED is

* To whom correspondence should be addressed.

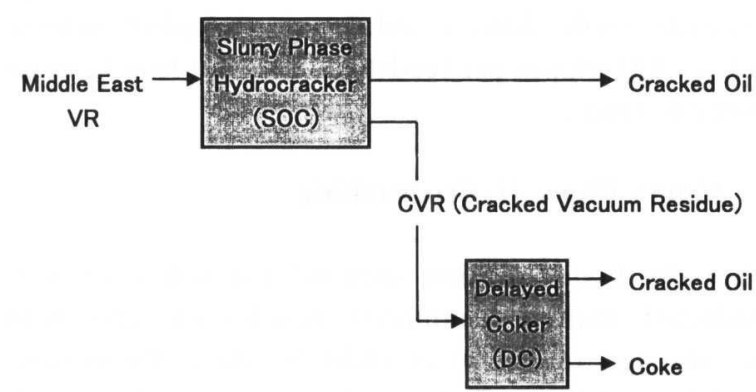

Fig. 1 Conceptual Flow Diagram of SUCCEED Process

illustrated in Fig. 1. The cracked vacuum residue (CVR) from the hydrocracker is fed to the delayed coker. The SUCCEED catalyst has been found suitable for overcoming coking problems and for conversion of heavy oil feedstocks into lighter and more valuable oil products.

This paper describes the features and performance of the SUCCEED process, and its potential application to the refineries now in operation.

\section{Catalyst for Slurry Phase Hydrocracking}

Many kinds of disposable catalysts have been reported for slurry phase catalytic processes ${ }^{1)-3)}$. Generally, mixtures of fine particle powder and metals are used, for example, pulverized coal impregnated with iron sulfate, iron oxide and spent hydrotreating catalysts. 
The SUCCEED catalyst is basically the same as that of SOC process ${ }^{1)-3)}$. It comprises two components, a molybdenum compound and ultrafine carbon powder of less than 1 micrometer. The components are dispersed into the fuel oil to give a slurry catalyst. The dispersed carbon has the role of trapping the coke materials and coke precursors and preventing coke deposition on the reactor wall in the hydrocracking section. The slurry keeps the dispersion uniform even without stirring at preheating temperature. A small amount of the slurry catalyst is mixed with the feedstock continuously fed to the hydrocracking reactor.

Figure 2 shows the effects of molybdenum addition in the slurry phase hydrocracking reaction in the batchwise autoclave experiments. The difference between the results of no addition of molybdenum and the addition of a low concentration of molybdenum such as 50 wtppm per feedstock was obvious. Such a small addition of molybdenum is economically acceptable even if it was not recovered. Moreover, such a small amount of molybdenum addition seems to have sufficient hydrogenation activity to quench the radical species produced from thermal cracking. Such addition of molybdenum gives the following favorable effects: (1) to reduce coke formation, (2) to increase yields of cracked oils, and (3) to surpress over-cracking. However, molybdenum addition in a higher amount such as 300 wtppm per feedstock does not lead to more favorable effect.

\section{Slurry Phase Hydrocracking}

For the hydrocracking section, research work was conducted with a continuous bench-scale unit with once-through operation in order to study the process variables and their effects on the process performance. A flow diagram of the bench-scale unit is shown in Fig.
3. A mixture of feedstock and catalyst slurry was pumped into the preheater section and combined with hydrogen gas. The mixture passing through the preheater was fed to the reactor bottom. The reactor was operated in the upflow manner. Conversion, hydrogen consumption, coke yield and coke build-up on the reactor tube wall (coking rate) for each set of reaction conditions were investigated.

Table 1 shows typical reaction conditions and the experimental results obtained from the bench testing.

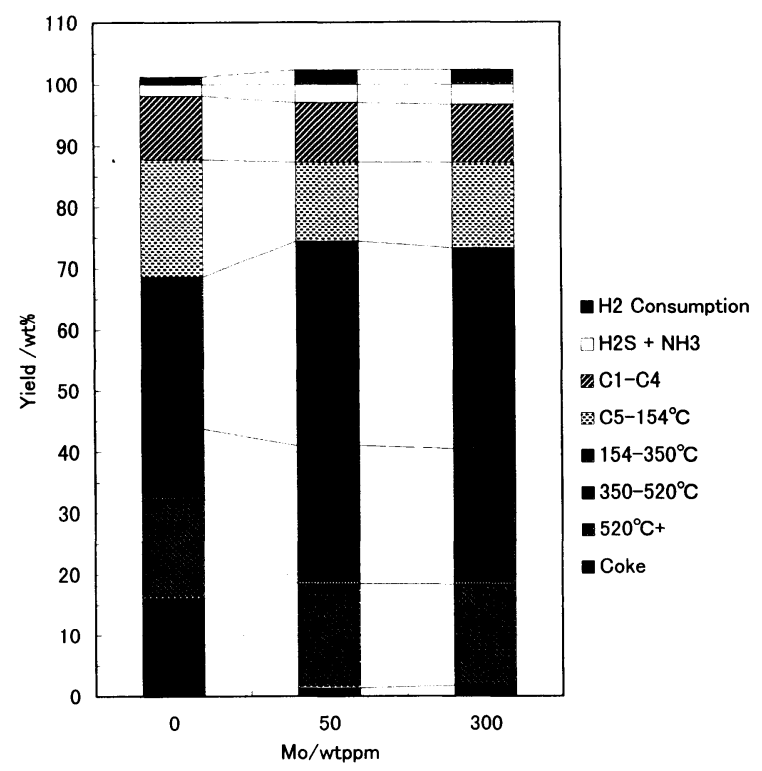

Reaction conditions:

feedstock, Middle East VR; carbon added, 2000 ppm; initial hydrogen pressure at room temperature, $120 \mathrm{~kg} / \mathrm{cm}^{2} \mathrm{G}$; initial ratio of hydrogen to oil, $360 \mathrm{~N} / \mathrm{kg}$; reaction temperature, $450^{\circ} \mathrm{C}$; reaction time at $450^{\circ} \mathrm{C}, 20 \mathrm{~min}$.

Fig. 2 Yields of Autoclave Slurry Phase Hydrocracking Reactions

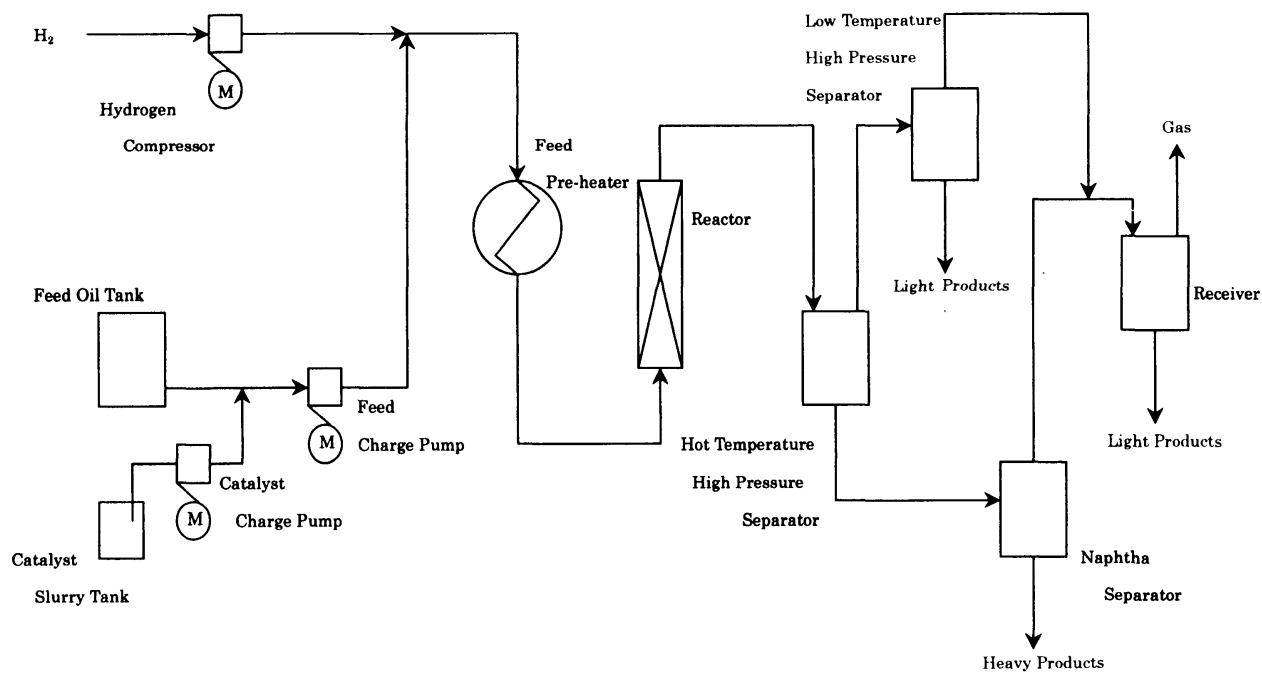

Fig. 3 Flow Diagram of the Hydrocracking Bench-scale Unit 
Table 1 Experimental Conditions and Results of Slurry Phase Hydrocracking

\begin{tabular}{|c|c|c|c|c|c|c|c|}
\hline Run & 1 & 2 & 3 & 4 & 5 & 6 & 7 \\
\hline Feedstock $^{\text {a) }}$ & A & A & ME & ME & ME & ME & ME \\
\hline \multicolumn{8}{|l|}{ Catalyst } \\
\hline Carbon & 3000 & 3000 & 3000 & 3000 & 3000 & 2000 & 2000 \\
\hline [ppm] & 100 & 100 & 100 & 100 & 100 & 50 & 50 \\
\hline Feed rate & 1.2 & 1.5 & 1.2 & 1.2 & 1.2 & 1.2 & 1.2 \\
\hline$\left[\mathrm{kg} / \mathrm{cm}^{2} \mathrm{G}\right]$ & 220 & 220 & 220 & 220 & 100 & 220 & 220 \\
\hline Temperature & 740 & 758 & 740 & 740 & 740 & 740 & 748 \\
\hline Conversion $^{\text {b) }}$ & 42 & 63 & 63 & 65 & 64 & 64 & 74 \\
\hline Coking rate ${ }^{\mathrm{c})}[\mathrm{ppm} /$ feed $]$ & 150 & 310 & 24 & 23 & 190 & 27 & 50 \\
\hline
\end{tabular}

a) A: VR derived from Asian crude, ME: VR derived from Middle East crude.

b) Defined as $\left\{1-\right.$ (weight of $565^{\circ} \mathrm{C}$ heavier in product)/(weight of $565^{\circ} \mathrm{C}$ heavier in feedstock $\} \times 100$.

c) Defined as (weight of coke stayed on reactor wall after reaction)/(total feedstock weight).

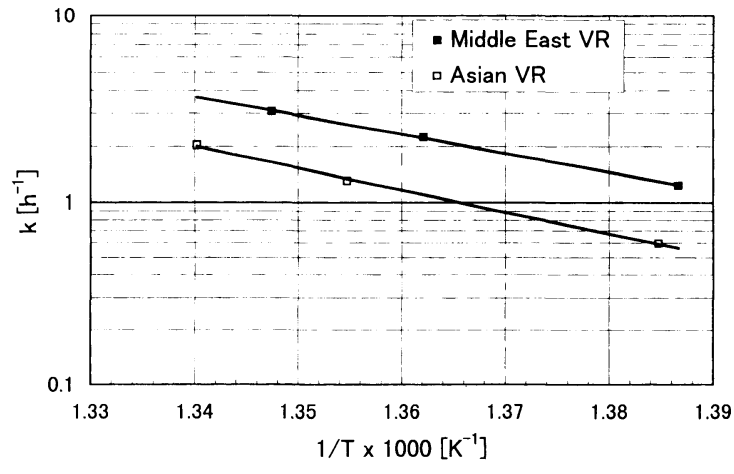

Fig. 4 Arrhenius Plots for the Hydrocracking Reaction

Feedstocks for these experiments were vacuum residues (VR) derived from Middle East crude, which is of aromatic composition, and Asian crude, which is of paraffinic composition. The properties of the VRs are as follows: for the Middle East VR, H/C: 1.37 $\mathrm{mol} / \mathrm{mol}$; factor of aromaticity $\left(F_{\mathrm{a}}\right)$ determined by ${ }^{13} \mathrm{C}$ NMR, 0.36; and for the Asian VR, H/C: $1.60 \mathrm{~mol} / \mathrm{mol}$; $F_{\mathrm{a}}, 0.21$.

Arrhenius plots for the cracking reaction for the two kinds of feedstocks are shown in Fig. 4. The cracking reactivity of the Middle East VR was much higher than that of the Asian VR. The use of the Middle East VR yielded approximately $20 \%$ higher conversion at the same reaction temperature $(740 \mathrm{~K})$ than that of the Asian VR (Run 1 and Run 3), and the former gave much lower coking rate. The Middle East VR showed approximately one sixth coking rate of the Asian VR (Run 1 and Run 3). The selection of feedstock greatly influenced the performance of the slurry phase hydrocracking process. Low hydrogen pressure gave a high coking rate (Run 5). However, the amount of the catalyst added could be moderately reduced without increasing the coking rate (Run 6). A higher conversion level $(74 \mathrm{wt} \%)$ can be achieved at the coking rate of $50 \mathrm{ppm} /$ feed using a lower concentration of the catalyst. The coking rate suggests that commercial plants
Table 2 Properties of Middle East VR Feedstock and the Product Oils Obtained from Slurry Phase Hydrocracking

\begin{tabular}{lrlllc}
\hline & & $\begin{array}{l}\text { Specific } \\
\text { gravity }\end{array}$ & $\begin{array}{l}\text { Sulfur } \\
\text { [wt\%] }\end{array}$ & $\begin{array}{l}\text { Nitrogen } \\
\text { [wtppm] }\end{array}$ & $\begin{array}{l}\text { Bromine } \\
\text { number }\end{array}$ \\
\hline Feedstock & & 1.0575 & 5.63 & 4200 & \\
Naphtha & $\left(\right.$ less than $\left.170^{\circ} \mathrm{C}\right)$ & 0.7106 & 0.129 & 450 & 31 \\
Kerosene & $\left(170-270^{\circ} \mathrm{C}\right)$ & 0.8163 & 1.01 & 980 & 24 \\
Gas oil & $\left(270-390^{\circ} \mathrm{C}\right)$ & 0.8789 & 2.07 & 1500 & 20 \\
VGO & $\left(390-520^{\circ} \mathrm{C}\right)$ & 0.9516 & 2.78 & 3000 & 21 \\
\hline
\end{tabular}

can be operated continuously for over a year, the detail of which is discussed in Section 5 .

The properties of the Middle East VR feedstock and the product oil obtained from Run 6 are summarized in Table 2.

\section{Thermal Cracking}

In refinery operations, the capacity of delayed coker is usually much larger than the amount of cracked vacuum residue (CVR) produced from the hydrocracker. In other words, CVR is cracked under the mixed condition with other feedstocks in thermal cracking.

For the thermal cracking section, research work was performed with autoclaves in batchwise operation to investigate the product yields under such condition. The CVR obtained by hydrocracking was mixed with virgin vacuum residue (VVR) derived from Middle East crude oil as the experimental feedstock. Reaction conditions of the autoclave experiments were adjusted to reproduce exactly the same yield from our commercial scale delayed coker.

Typical results of coking experiments are shown in Fig. 5. The less CVR in the feedstock, the smaller was the coke yield from CVR. In the Fig. 5, an extrapolation to zero CVR feedstock corresponds to 32 $\mathrm{wt} \%$ that is the coke yield from VVR. The ratio of CVR to VVR should be chosen according to the refinery scheme and material balance. 


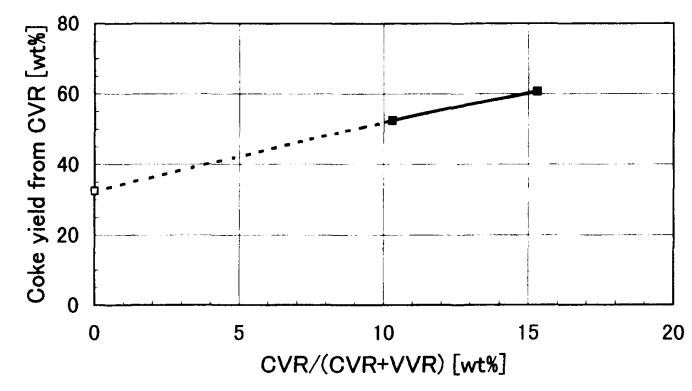

Fig. 5 Coke Yields from CVR by Thermal Cracking

\section{Proposed Process}

We propose a new combination process of slurry phase hydrocracking and thermal cracking for upgrading of residual oil. A simplified flow diagram of the hydrocracking section is shown in Fig. 6. The first section was designed by modification of SOC process ${ }^{1), 2}$. The following points were modified: (1) no recycle stream fed to the reactor, (2) addition of ADIP scrubber for removal of $\mathrm{H}_{2} \mathrm{~S}$ produced from the sour feedstock, and (3) improvement for anti-coking in the recovery section.

The SOC demonstration plant had been operated from 1987 to 1989, and it converted solely an Asian paraffinic VR at about $80-90 \mathrm{wt} \%$ conversion. However, the coke build-up on the reactor tube wall permitted us to operate continuously for only 3 months (with a coking rate of more than $150 \mathrm{wtppm}$ of feed). In this study, mild coking conditions, which resulted from lower levels of conversion and from the coking properties of the feedstock, allowed us to achieve longer and more stable operation without coking throughout the process as evidenced by the decrease in the coking rate shown in Table 1 . Having achieved a lower coking rate such as 30 wtppm of the feed, it suggested that a commercial-scale plant could be operated continuously for over a year because the run length in this reactor system is inversely proportional to the coking rate on the reactor tube wall.

The typical product yields of SUCCEED process, product yields of hydrocracking section together with those of thermal cracking section are shown in Table 3. The right half of Table $\mathbf{3}$ indicates the yields from CVR in thermal cracking mixed with VVR at the CVR mixing ratio of $13 \mathrm{wt} \%$. Thus, the total conversion of $85 \mathrm{wt} \%$, together with the yields of the products, was confirmed.

\section{Conclusions}

A new combination process, SUCCEED, for residual oil cracking, has been introduced. In the slurry phase catalytic hydrocracking, moderate levels of conversions (63-74 wt\%) at low coking rates in once-through mode operation were achieved in the bench tests. The total $85 \mathrm{wt} \%$ conversion combined with the second section, delayed coking, was also proven. The process variables for the hydrocracking and their effects on the process performance were studied. The mild coking conditions were attributed by moderate conversion, by non-recycle operational mode and by the aromatic nature of the feedstock. These contributions allowed us to achieve stable longer-term operation without

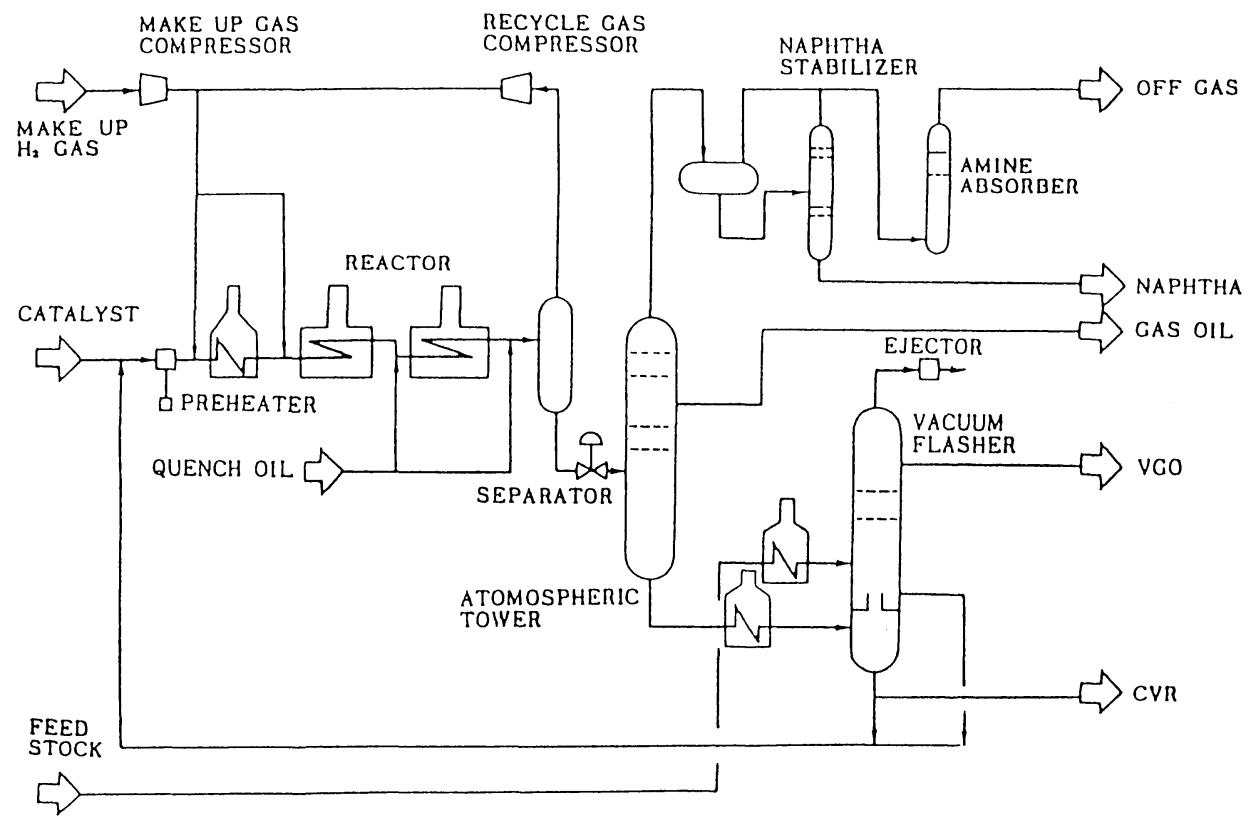

Fig. 6 Simplified Flow Diagram of the Hydrocracking Section 
Table 3 Typical Product Yields in SUCCEED Process

\begin{tabular}{|c|c|c|c|c|c|c|}
\hline \multicolumn{3}{|c|}{ Slurry phase hydrocrackinga) } & \multicolumn{4}{|c|}{ Thermal cracking } \\
\hline Feed oil & [vol] & 100 & Feed CVR & [vol] & 100 & (more than $565^{\circ} \mathrm{C}$ ) \\
\hline Hydrogen & {$\left[\mathrm{Nm}^{3} /\right.$ Feed-kl] } & 150 & & & & \\
\hline Product & [vol\%] & & Product & [vol\%] & & \\
\hline LHC (FOE) & & 10.1 & LHC (FOE) & & 9.0 & \\
\hline Naphtha & $\left(50-170^{\circ} \mathrm{C}\right)$ & 11.8 & Naphtha & & 11.1 & $\left(50-170^{\circ} \mathrm{C}\right)$ \\
\hline Kerosene-Gas oil & $\left(170-390^{\circ} \mathrm{C}\right)$ & 26.8 & Kerosene-Gas oil & & 23.8 & $\left(170-390^{\circ} \mathrm{C}\right)$ \\
\hline Vacuum gas oil & $\left(390-565^{\circ} \mathrm{C}\right)$ & 30.9 & Vacuum gas oil & & 19.0 & $\left(390-565^{\circ} \mathrm{C}\right)$ \\
\hline CVR & (more than $565^{\circ} \mathrm{C}$ ) & 34.0 & Liquid product total & & 62.9 & \\
\hline Product total & & 113.6 & Coke & {$[\mathrm{wt} \%]$} & 55.0 & \\
\hline
\end{tabular}

a) Reaction conditions and feedstock properties are shown in Table 1 (Run 6) and Table 2, respectively.

b) Mixing ratio of CVR into feedstock is $13 \mathrm{wt} \%$.

undue coking through-out the process.

There are quite a few delayed coker units in the world. Thus, SUCCEED could be one of the effective, commercially practical processes for residual oil cracking in the future.

\section{Acknowledgments}

Part of this work has been sponsored by Petroleum Energy Center in Japan, which is supported by Ministry of International Trade and Industry.

\section{References}

1) Seko, M., Ohtake, N., Kuri, K., Kato, K., Asakura, N., AIChE Symposium Series, 85, 43 (1989).

2) Research Association for Residual Oil Processing (RAROP), "RAROP Heavy Oil Processing Handbook," ed. by Kamiya, K., RAROP, (1991), p. 47-82.

3) Kato, K., Ishibashi, Y., Saito, A., Ishida, K., Prepr. Am. Chem. Soc. Div. Petrol. Chem., 42, 454 (1996).

要旨

\title{
使い捨て触媒を用いる新規な組合せ重質油分解プロセス
}

\author{
加藤 恒一 ${ }^{\dagger 1)}$, 石田 勝昭 ${ }^{\dagger 2}$, 石橋 泰 ${ }^{\dagger 3}$, 斎藤 彰 ${ }^{\dagger 3}$ \\ †1) 日鉱エンジニアリング(株)，105-0001 東京都港区虎ノ門 4-1-10 \\ †2)（株) ジャパンエナジー 精製技術センター，335-0026 埼玉県戸田市新曽南 3-17-35 \\ †3)（株）ジャパンエナジー 水島製油所，712-8054 岡山県倉敷市潮通 2-1
}

石油残油の分解を目的とした新規な分解反応プロセスを開発 した。スラリー床の水素化分解と熱分解との組合せからなる 「サクシード」プロセスは, ベンチスケールテストの結果によ り工業的に実現可能と考えられる。

最初のセクション,「サクシード」の主要部分である水素化 分解においては, 管反応器と使い捨て超微細触媒を使用する。 原料は減圧残油であり, 最初のセクションは約 $65 \mathrm{wt} \%$ 程度の 分解をする。後段セクションはディレードコーキングであり，
最初のセクションで分解されなかった残さを $55 \mathrm{wt} \%$ 程度分解 する。したがって, 総合分解率 $85 \%$ の反応が起こる。

使い捨て触媒の二つの機能, すなわち水素化機能と反応器コ 一キング抑制機能について検討し, 必要十分な添加量を求め た。

本論文では,「サクシード」プロセスの特徵, 触媒およびプ ロセス性能，実製油所における利用の可能性について述べる。

\section{Keywords}

Combination process, Heavy oil cracking, Disposable catalyst, Coking, Molybdenum 